\title{
Zmena pravidla o 3-bodovom území a jej vplyv na početnost' a úspešnost' strel'by za 3 body u vrcholových basketbalistov U16 a U18
}

\section{The Change of 3-point Field Goal Area Rule and Its Impact on the Number of Attempts and Successfulness of the 3-point Shooting of Elite Male Basketball Players U16 and U18}

\author{
Tomáš Vencúrik
}

Fakulta sportovních studií Masarykovy univerzity, Brno

\begin{abstract}
Abstrakt
Príspevok sa zaoberá vplyvom zmeny pravidla o 3-bodovom území (zmena horizontálnej vzdialenosti z 6,25 m na 6,75 m od koša) na početnost' a úspešnost'strel'by za 3 body, vo vekových kategóriách mužov do 16 rokov (U16) a do 18 rokov (U18). Výskumný súbor bol tvorený družstvami, ktoré sa zúčastnili Majstrovstiev Európy (ME) v rokoch 2009, 2010, 2011 a 2012 v kategóriách U16 a U18. Celkovo bolo analyzovaných 548 herných štatistík zo všetkých odohratých zápasov v oboch vekových kategóriách.

Pri porovnaní početnosti 3-bodových pokusov pred (ME 2009, 2010) a po zmene pravidiel (ME 2011, 2012), sme zistili signifikantý rozdiel v kategórii U16 (21,32 $\pm 5,58$ vs. 18,31 $\pm 0,28 ; p<0,01)$, podobne ako v kategórii U18 $(22,49 \pm 5,14$ vs. 20,01 $\pm 5,46 ; p<0,01)$. V percentuálnej úspešnosti strel'by za 3 body medzi porovnávanými ME 2009, 2010 a ME 2011, 2012 neboli zistené štatisticky významné rozdiely v U16 (28,03 $\pm 10,17 \%$ vs. 27,89 $\pm 10,28 \% ; p>0,05)$, ani v U18 (29,62 $\pm 10,51 \%$ vs. $29,24 \pm 9,77 \% ; p>0,05)$. Výsledky indikujú, že pravdepodobne došlo $k$ zmenám vo zvolených modeloch hry sledovaných družstiev, pričom v útočnej fáze hry bola preferovaná strel'ba za 2 body. Ďalej sa ukazuje, že časový interval medzi jednotlivými ME je dostatočne dlhé časové obdobie na adaptáciu sa hráčov novým pravidlám.
\end{abstract}

\begin{abstract}
The article deals with the impact of the change of 3-point field goal shooting area rule (change of horizontal distance from $6.25 \mathrm{~m}$ to $6.75 \mathrm{~m}$ from the basket) on the number of attempts and the successfulness of the 3-point shooting in age categories under 16 (U16) and under 18 (U18) years old male basketball players. The research sample consists of teams which took part in European Championships (ECH) in years 2009, 2010, 2011 and 2012 in categories U16 and U18. Analyzed were 548 game statistics of all games played in both categories.

When we compared the number of 3-point shooting attempts, before (ECH 2009, 2010) and after the change of rules (ECH 2011, 2012), we found a statistically significant difference in U16 (21.32 \pm 5.58 vs. $18.31 \pm 10.28$; $p<0.01)$ and also in U18 (22.49 \pm 5.14 vs. $20.01 \pm 5.46 ; p<0.01)$. When the percentage of 3-point shooting successfulness was compared between ECH 2009, 2010 and ECH 2011, 2012 the statistically significant differences were not determined in U16 $(28.03 \pm 10.17 \%$ vs. $27.89 \pm 10.28 \%$; $p>0.05)$ as well as in U18 $(29.62$ $\pm 10.51 \%$ vs. $29.24 \pm 9.77 \% ; p>0.05$ ). The results indicate that changes probably appeared in chosen models of game of monitored teams, therefore the preferred shooting in offensive phase of game was 2-point shooting. Furthermore, it was proved that the time period between individual ECH is long enough for the adaptation of players to the new rules.
\end{abstract}

Kl'účové slová: basketbal, 3-bodová strel'ba, zmena pravidiel o 3-bodovom území, početnost'strel'by, úspešnost' strel'by

Key words: basketball, 3-point shooting, change of 3-point field goal area rule, shooting attempts, successfulness of shooting 


\section{ÚVOD}

Basketbal je celosvetovo populárna kolektívna športová hra, ktorá prechádza od svojho vzniku v roku 1891 neustálym vývojom a zmenami v oblasti pravidiel. K zmene pravidiel pristupuje Medzinárodná basketbalová federácia (FIBA) na základe priblíženia a zatraktívnenia hry podl'a sút’aže Národnej basketbalovej asociácie (NBA) a tým spojenými vývojovými tendenciami v basketbale. Táto snaha o zjednotenie pravidiel má samozrejme dopad na jednotlivé faktory (technicko-taktické, fyziologické, atd'.) ovplyvňujúce herný výkon v zápase. Posledné zmeny pravidiel sa dotkli aj basketbalovej strel'by a to konkrétne strel'by za 3 body.

Vít'azstvo v zápase závisí od viacerých faktorov a je limitované počtom bodov, ktoré dosiahne družstvo v porovnaní so súperom. Body v zápase je možné dosiahnut' jedine úspešnou strel'bou. Gómez et al. (2008), Ibañez et al. (2009) a Lorenzo et al. (2010) poukazujú na dôležitost' 2-bodovej strel'by, ako jedného zo štatistických ukazovatel'ov herných činností jednotlivca zaznamenávaných v hernej štatistike, a jej signifikantného vplyvu na vít'azstvo v zápase. Basketbalovú strel'bu, podobne ako aj d’alší autori (McGee \& ASEP, 2007; Brodzinski, 2007; Krause et al., 2008; Mačura, 2010; Wissel, 2012), považujeme za nenahraditel'nú a najdôležitejšiu útočnú hernú činnost' jednotlivca. Zavedenie 3-bodovej strel'by v NBA (vzdialenost' 7,24 m - 23 stôp a 9 palcov) v roku 1979 výrazne zmenilo basketbal, čím sa ešte viac zatraktívnil. Súhlasíme s názorom Tománka (2010), že strel'ba za 3 body sa stala od svojho zavedenia významným komponentom v ofenzívnych a defenzívnych plánoch trénerov. FIBA prvýkrát zaviedla pravidlo o strel'be za 3 body na $\mathrm{OH}$ v Los Angeles v roku 1984 zo vzdialenosti $6,25 \mathrm{~m}$. K zmene a posunutiu hranice na 6,75 m došlo až 1 . októbra 2010, pričom po celých 26 rokov bola táto vzdialenost' konštantná. 3-bodové územie podl’a pravidiel FIBA je uvedené na obr. 1. Podl’a Argaja $(2009,2011)$ má pri hodnotení hernej efektivity v zápase úspešná 3-bodová strel'ba, ako jeden z kladných kritických prípadov, najvyšší index významnosti. Úspešnost' strel'by za 3 body môže byt' ovplyvnená viacerými faktormi. Pates et al. (2002) uvádzajú ako faktor zvyšujúci úspešnost' 3-bodovej strel'by vplyv relaxačných metód, Oudejans (2012) zase špeciálny vizuálny tréningový program. Kinematické rozdielnosti v strel'be, ktoré môžu taktiež vplývat' na úspešnost', zistili Miller \& Bartlett (1996) medzi jednotlivými hráčskymi funkciami a z rozdielnych horizontálnych vzdialeností. K podobným výsledkom dospeli vo svojej štúdií aj Erčulj \& Supej (2009), pričom zistili signifikantné pôsobenie zvyšujúcej sa zát’ǎe na kinematiku streleckého pohybu zo vzdialenosti 7,24 m. Izokinetická sila v lakt’ovom kíbe mala vo výskume Tang \& Shung (2005) štatisticky významný vplyv na presnost' strel'by zo vzdialenosti $6,75 \mathrm{~m}$. Podl'a Tománka \& Kucsu (2012) došlo po posunutí 3-bodového územia na 6,75 m k štatisticky významnému poklesu úspešnosti strel'by v seniorskej kategórií mužov na Majstrovstvách Európy (ME) 2011 oproti Majstrovstvám sveta 2010. Krause et al. (2008) vo svojej práci uvádzajú požadovanú úspešnost' strel'by za 3 body v zápasových podmienkach pre hráčov stredných škôl na úrovni $30 \%$.

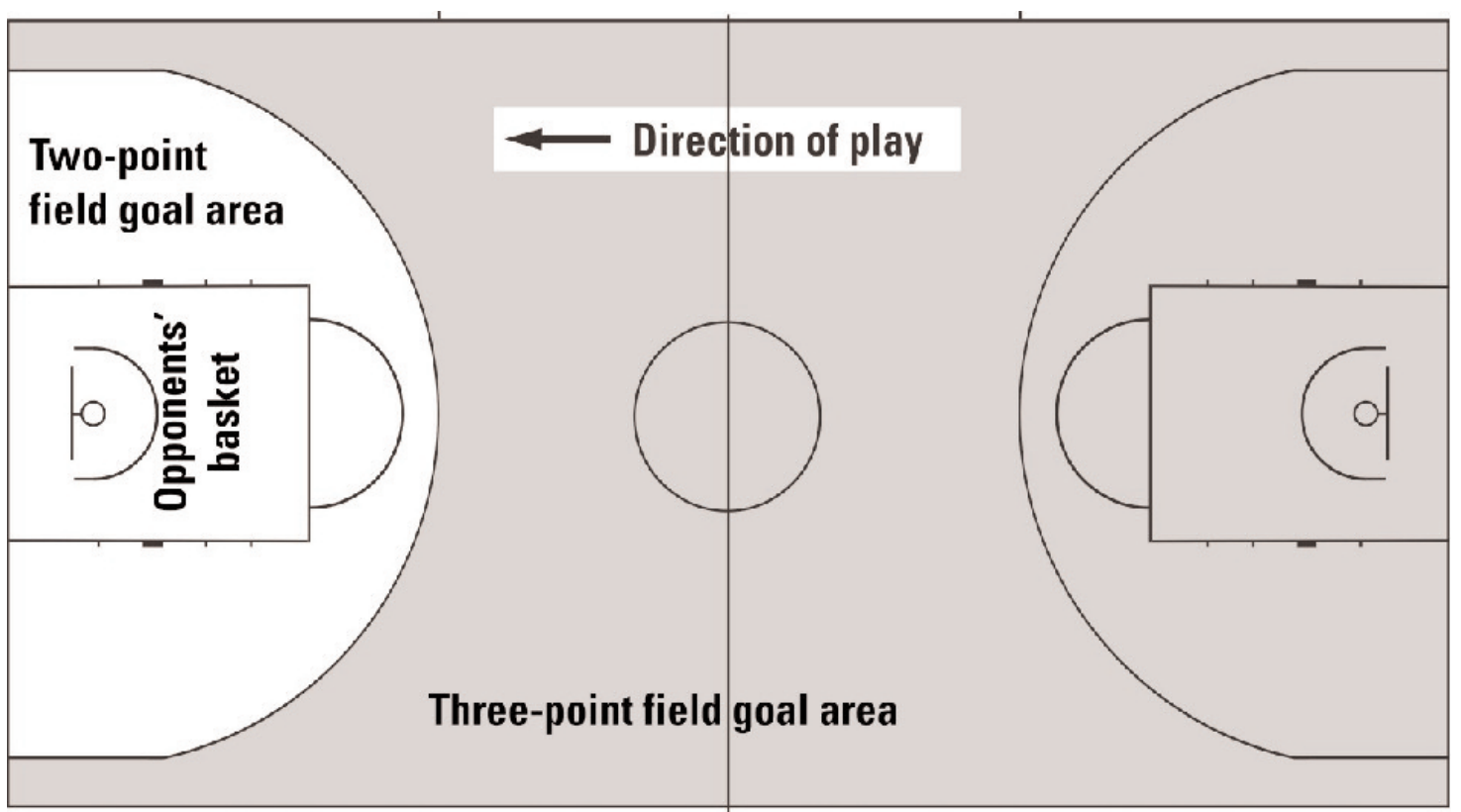

Obr. 1. 3-bodové územie podl'a FIBA platné od 1. októbra 2010 (FIBA, 2012) 


\section{Ciel'}

V roku 2010 došlo k zmene pravidiel týkajúcich sa hracej plochy, a jednou zo zmien bolo aj posunutie 3-bodového územia v horizontálnej vzdialenosti na 6,75 m od koša. Ciel’om práce je zistit', či po uplatnení nového pravidla došlo $\mathrm{k}$ zmenám v početnosti a úspešnosti strel'by za 3 body v kategóriách mužov U16 a U18 na ME v rokoch 2009, 2010, 2011 a 2012, ktoré sa hrajú pravidelne v ročnom intervale.

\section{METODIKA}

\section{Charakteristika výskumného súboru}

Výskumný súbor tvorili družstvá, ktoré sa zúčastnili ME divízie A v rokoch 2009, 2010, 2011 a 2012 v kategóriách mužov do 16 rokov (U16) a do 18 rokov (U18). V každom roku v oboch vekových kategóriách sa zúčastnilo ME 16 družstiev (spolu $\mathrm{n}=128$ ).

\section{Metódy získavania údajov}

Zámerom bolo vybrat' štyri po sebe nasledujúce vrcholové podujatia, v čo najkratšom časovom horizonte, medzi ktorými došlo k zmene pravidla o 3-bodovom území. ME divízie A v rokoch 2009 a 2010 boli v sledovaných vekových kategóriách poslednými vrcholovými podujatiami pred zmenou pravidla a ME divízie A v rokoch 2011 a 2012 boli prvými vrcholovými podujatiami po zmene pravidla o 3-bodovej strel'be. Údaje o početnosti a úspešnosti strel'by za 3 body sme získali analýzou herných štatistík jednotlivých zápasov odohratých na ME v rokoch 2009, 2010, 2011, 2012 z oficiálnych webových stránok FIBA

\section{Metódy spracovania a vyhodnocovania údajov}

$\mathrm{Na}$ každom podujatí ME sme analyzovali herné štatistiky všetkých zápasov, ktoré sa odohrali. Na ME v roku 2009 odohrali družstvá v každej kategórií 64 zápasov. Od ME v roku 2010 sa zmenil hrací systém sút’aže a družstvá odohrali na každom šampionáte už 70 zápasov. Údaje o početnosti a úspešnosti strel'by za 3 body sme vyhodnotili z herných štatistík z 268 zápasov pred zmenou pravidiel v oboch kategóriách spolu a z herných štatistík z 280 zápasov po zmene pravidiel taktiež v oboch kategóriách spolu. Spracovávali sme údaje o početnosti $(\mathrm{n}=1096)$ a úspešnosti strel'by za 3 body $(\mathrm{n}=1096)$ zo všetkých odohratých zápasov $(\mathrm{n}=548)$. Pri vyhodnocovaní získaných údajov sme použili opisné charakteristiky a to miery polohy a miery variability. Distribúciu normality dát sme overili Shapiro-Wilkovým testom. Na základe normality rozdelenia získaných dát sme pri porovnaní rozdielnosti v úspešnosti 3-bodovej strel'by medzi ME 2009, 2010 a ME 2011, 2012 použili parametrický t-test pre nezávislé vzorky. Na porovnanie rozdielnosti v početnosti 3-bodovej strel'by medzi ME 2009, 2010 a ME 2011, 2012 sme použili neparametrický Mann-Whitneyov U-test (Hendl, 2004; Chráska, 2007). Všetky štatistické testy významnosti sme vyhodnocovali v softwarovom programe Statistica 10 (StatSoft, Inc., Tulsa, USA). Významnost' rozdielov sme posudzovali na štandardných hladinách štatistickej významnosti $\mathrm{p}<0,05$, resp. $\mathrm{p}<0,01$.

\section{VÝSLEDKY A DISKUSIA}

Na ME 2009, 2010 v U16 bolo vystrelených spolu 5713 3-bodových pokusov, pričom na ME 2011, 2012 to bolo 5127 pokusov. Rozdiel predstavuje hodnota 586 pokusov. Pokles v početnosti strel'by za 3 body bol po zmene pravidiel na úrovni 10,3 \%. Do úvahy musíme brat' aj fakt, že na ME 2009, 2010 sa odohralo spolu o 6 zápasov menej, ako na ME 2011, 2012. V zápasoch U16 dosiahli družstvá priemerné hodnoty v 3-bodových streleckých pokusoch na zápas 21,97 $\pm 5,14$ (ME 2009), 20,72 $\pm 5,91($ ME 2010), 18,31 $\pm 4,82($ ME 2011) a 18,31 $\pm 5,29$ (ME 2012). Od ME 2009 pozorujeme klesajúcu tendenciu v počte streleckých pokusov za 3 body (obr. 2). Priemerná početnost' 3-bodovej strel’by na zápas v U16 bola pred zmenou pravidiel 21,32 \pm 5,58 a po zmene pravidiel priemerne $18,31 \pm 10,28$, čo predstavuje rozdiel na úrovni $14,1 \% \mathrm{v}$ priemernom počte striel za 3 body na zápas. V porovnaní s Lorenzom et al. (2010), ktorí uvádzajú priemerne 22,4 vystrelených lôpt za 3 body na ME 2004, 2005 v kategórií U16, došlo k poklesu na všetkých sledovaných ME. Na základe Mann-Whitneyho U-testu sme zistili signifikantné rozdiely medzi početnost'ou strel'by na ME 2009, 2010 pred zmenou pravidiel a na ME 2011, 2012 po zmene pravidiel o 3-bodovom území ( $\mathrm{p}<0,01)$.

Vo vekovej kategórií U18 na ME 2009, 2010 bolo vystrelených 6028 lôpt spoza 3-bodového oblúka a na ME 2011, 2012 to bolo spolu 5603 pokusov. Po zmene pravidiel sa znížil počet pokusov za 3 body o 425 
striel, čo predstavuje pokles o 7,1 \%. V rokoch 2009, 2010 sa odohralo taktiež o 6 zápasov menej ako v rokoch 2011, 2012. V zápasoch U18 dosiahli družstvá priemerné hodnoty početnosti v strel'be za 3 body na zápas 21,83 \pm 4,86 (ME 2009), 23,1 $\pm 5,33$ (ME 2010), $21 \pm 5,39$ (ME 2011) a 19,02 $\pm 5,36$ (ME 2012). Na ME 2010 došlo k vzrastu v počte pokusov strel'by za 3 body oproti ME 2009, ale na nasledujúcich ME 2011 a 2012 môžeme pozorovat' klesajúci trend v tomto štatistickom ukazovateli (obr. 2). Pred zmenou pravidiel, a teda zo vzdialenosti $6,25 \mathrm{~m}$, bola priemerná početnost' strel'by na ME 2009, 2010 na zápas 22,49 $\pm 5,14$ pokusov. Po zmene pravidiel, zo vzdialenosti $6,75 \mathrm{~m}$, klesol priemerný počet vystrelených lôpt na ME 2011, 2012 na úroveň 20,01 $\pm 5,46$ pokusov. Rozdiel v priemernom počte streleckých pokusov za 3 body na zápas bol 11 \%. Goméz et al. (2008) vo svojej štúdií prezentujú priemerný počet vystrelených lôpt za 3 body na zápas v najvyššej seniorskej Španielskej lige v sezóne 2004/2005 na úrovni 27,25 pokusov. Tománek \& Kucsa (2012) však uvádzajú priemernú početnost' 3-bodovej strel'by na MS 2010 seniorov až 46,61 pokusov a na ME 2011 o niečo nižšiu početnost' 40,16 pokusov na zápas. Z pohl'adu priemernej početnosti strel'by za 3 body v rôznych sút’ažiach a vekových kategóriách pozorujeme rozdielne javy. Môžeme konštatovat', že početnost' strel'by za 3 body je závislá od vekovej kategórie (U16, U18, seniori) a typu sút’aže (liga, ME, MS), pričom v seniorskej kategórií dochádza k častejšej strel’be za 3 body ako v mládežníckych kategóriách. Tento jav môže byt' pravdepodobne spôsobený nadobudnutými hernými skúsenost’ami hráčov, s tým spojeným vyšším sebavedomím a tiež ofenzívnymi plánmi trénerov. Pri porovnaní početnosti strel'by za 3 body v kategórií U18 medzi ME 2009, 2010 a ME 2011, 2012 po zmene pravidiel o 3-bodovom území sme zistili štatisticky významný rozdiel ( $<<0,01)$. Z výsledkov vyplýva, že významný pokles v početnosti strel'by za 3 body v kategóriách U16 a U18 bol spôsobený práve zmenou pravidiel o 3-bodovom území, teda posunutím horizontálnej vzdialenosti z 6,25 m na $6,75 \mathrm{~m}$. Je možné, že táto zmena pravidiel mala vplyv aj na zvolenú taktiku trénerov, ktorí uprednostňovali v útočných herných systémoch strel'bu z kratších vzdialeností a nepreferovali strel'bu za 3 body.

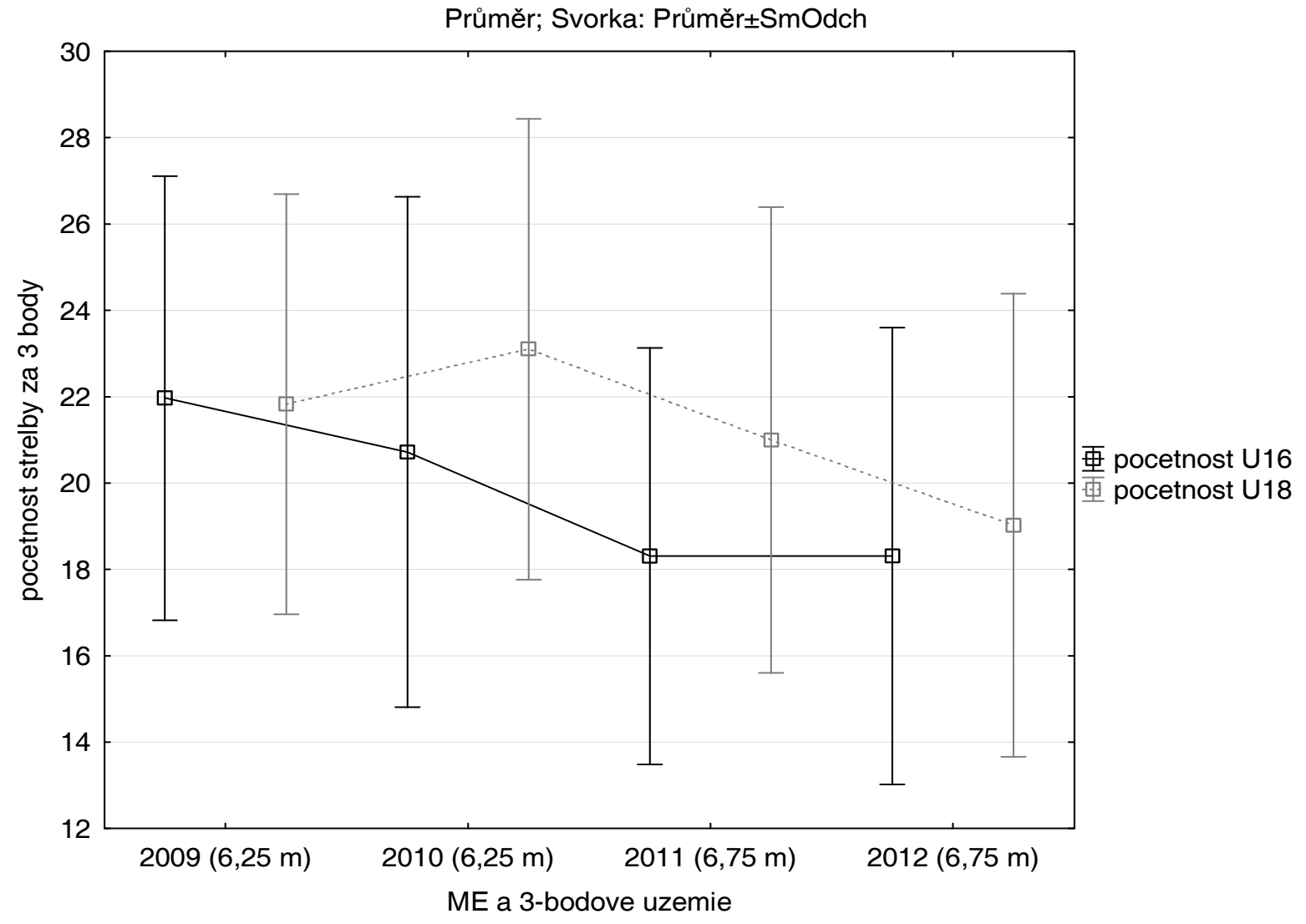

Obr. 2. Početnost' 3-bodovej strel'by U16 a U18 na ME v rokoch 2009, 2010, 2011 a 2012 
V kategórií U16 dosiahli družstvá priemernú úspešnost' v 3-bodovej strel'be 29 ะ 10,64 \% (ME 2009), 27, 14 $\pm 9,67 \%$ (ME 2010), 27,31 $\pm 10,18 \%$ (ME 2011) a 28,47 $\pm 10,39 \%$ (ME 2012) na zápas (obr. 3). Pred zmenou pravidiel na ME 2009, 2010 bola priemerná úspešnost' strel'by za 3 body 28,03 $\pm 10,17 \%$. Po zmene pravidiel na ME 2011, 2012 bola priemerná úspešnost' strel'by o niečo nižšia 27,89 $\pm 10,28 \%$, čo predstavuje pokles len o 0,5 \%. Pri porovnaní úspešnosti strel’by v kategórií U16 medzi ME 2009, 2010 a ME 2011, 2012 sme nezistili signifikantné rozdiely $(\mathrm{p}>0,05)$. Zaujímavost'ou je aj fakt, že pred zmenou pravidiel bola najnižšia úspešnost' strel'by za 3 body $5,6 \%$, pričom po zmene pravidiel sa vyskytli zápasy, v ktorých bola úspešnos na úrovni $0 \%$. Dosiahnutá úspešnost' 3-bodovej strel'by, ako pred, tak aj po zmene pravidiel, je porovnatel'ná s Lorenzom et al. (2010), ktorí uvádzajú úspešnost' v U16 na ME 2004, 2005 na úrovni 28,9\%.

V kategórií U18 bola priemerná úspešnost' 3-bodovej strel'by 30,36 $\pm 10,04 \%$ (ME 2009), 28,95 \pm 10,92 \% (ME 2010), 29,49 \pm 10,63 \% (ME 2011) a 29,02 \pm 8,87 \% (ME 2012) na zápas (obr. 3). Pred zmenou pravidiel, na ME 2009, 2010, bola priemerná úspešnost' 3-bodovej strel'by družstiev na úrovni 29,62 $\pm 10,51 \%$ na zápas. Po zmene pravidiel, na ME 2011, 2012, dosiahli sledované družstvá priemer 29,24 $\pm 9,77$ \% na zápas. Po posunutí hranice pre strel'bu za 3 body na $6,75 \mathrm{~m}$, došlo $\mathrm{k}$ poklesu v úspešnosti strel'by o 1,2 \% na zápas. Pri porovnaní úspešnosti strel'by pred zmenou pravidiel (ME 2009, 2010) a po zmene pravidiel (ME 2011, 2012) o 3-bodovej strel'be sme nezaznamenali štatisticky významné rozdiely ( $\mathrm{p}>0,05)$. Najnižšia úspešnost' strel'by na ME 2009, 2010 bola 5,9 \%, pričom na ME 2011, 2012 bola v niekol'kých zápasoch $0 \%$.

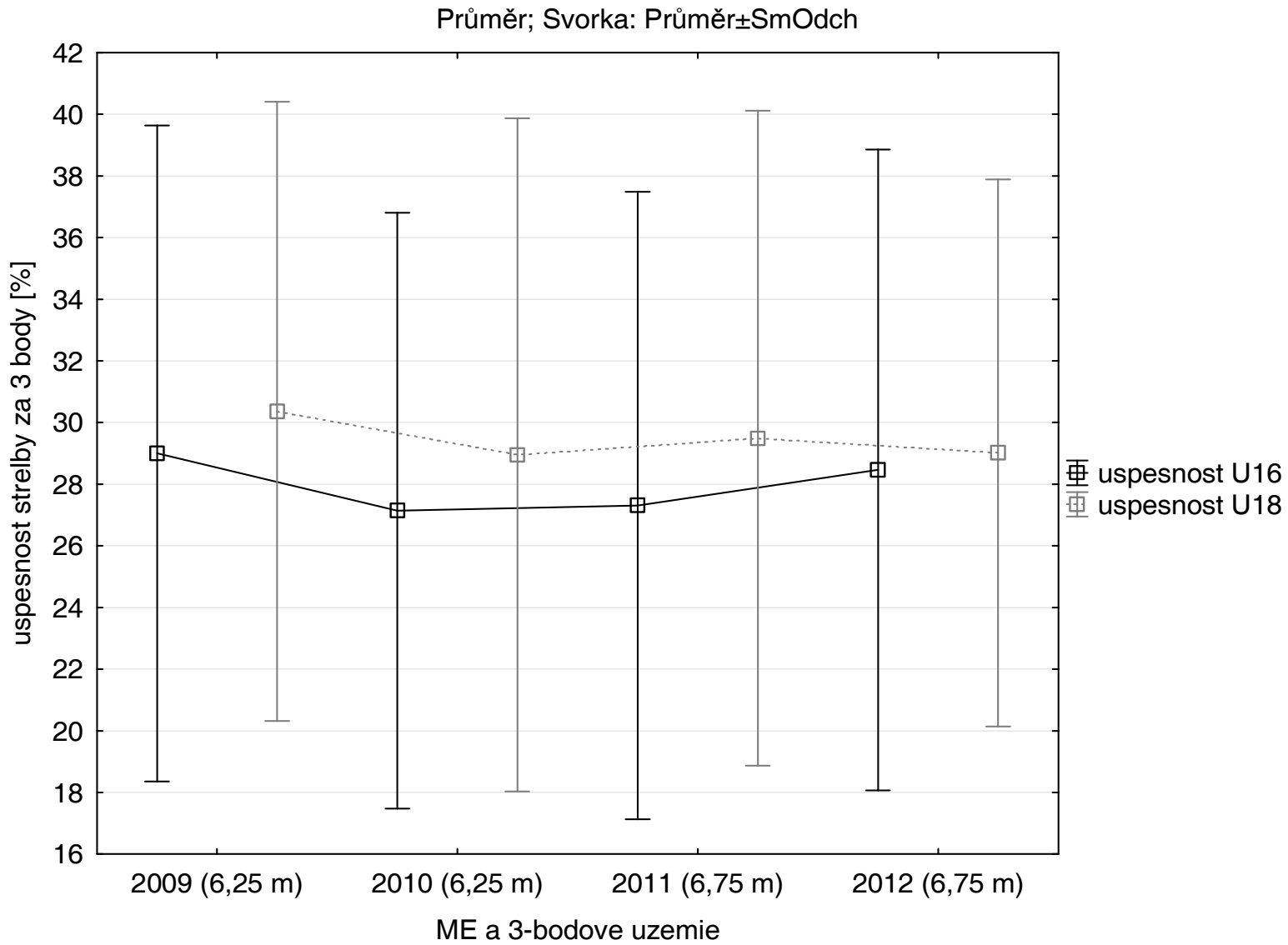

Obr. 3. Percentuálna úspešnost' 3-bodovej strel'by U16 a U18 na ME v rokoch 2009, 2010, 2011 a 2012

Neto (2007), Pojskić et al. (2009) a Tománek \& Kucsa (2012) uvádzajú úspešnost' 3-bodovej strel'by v seniorskej kategórií mužov na rôznych vrcholových podujatiach v rozmedzí 32 až 37 \%. Musíme brat' ohl’ad aj na fakt, že sledované družstvá hrali vo vekových kategóriách U16 a U18, pričom najväčší rozdiel bude pravdepodobne už v spomenutých nadobudnutých herných skúsenostiach hráčov seniorskej kategórie. Tománek 
\& Kucsa (2012) uvádzajú signifikantný rozdiel v úspešnosti strel’by za 3 body medzi seniorskými MS 2010 a ME 2011. V našom prípade nedošlo $\mathrm{k}$ štatisticky významnému poklesu $\mathrm{v}$ úspešnosti 3-bodovej strel'by v U16 a U18 medzi ME 2009, 2010 a ME 2011, 2012 po zmene pravidiel. Ako hlavný dôvod môže byt' práve fluktuácia hráčskeho kádra v U16 a U18, ked’že v seniorskej kategórií dochádza k zmenám v zložení družstiev len výnimočne. Ďalším dôvodom bolo pravdepodobne časové rozpätie sledovaných vrcholových podujatí. ME v týchto vekových kategóriách sa hrajú v pravidelnom ročnom intervale, čo znamená, že družstvá mali dostatok času (v klubovej aj v reprezentačnej príprave) na adaptáciu sa novému pravidlu o 3-bodovom území. Podl'a Millera \& Bartletta (1996) sa zo zväčšovaním horizontálnej vzdialenosti mení aj kinematická štruktúra streleckého pohybu, a ročný, resp. 2-ročný interval mohol byt' dostatočne dlhým časovým úsekom na optimalizáciu správnej streleckej techniky z požadovanej vzdialenosti. Predpokladáme, že štatisticky významné rozdielnosti v úspešnosti strel'by za 3 body, by sa mohli potvrdit' práve pri analýze dlhodobých (ligových) sút’aží, kde časová adaptácia na zmenu pravidla bola podstatne kratší čas. Na základe výsledkov môžeme konštatovat', že po zmene pravidiel v roku 2010, a posunutí hranice 3-bodovej strel'by do vzdialenosti 6,75 m, došlo k zníženiu v početnosti 3-bodových streleckých pokusov. Je možné, že práve táto zmena mala vplyv na ofenzívne taktické plány trénerov, ktorí vo zvolených modeloch hry svojich družstiev pravdepodobne preferovali strel'bu z krátkych a stredných vzdialeností. Súhrne charakteristiky početnosti a úspešnosti strel'by za 3 body pred a po zmene pravidiel sú uvedené v tabul'ke 1 .

Tab. 1. Deskriptivna charakteristika sledovaných parametrov 3-bodovej strel'by pred a po zmene pravidiel

\begin{tabular}{|c|c|c|c|c|c|c|c|c|}
\hline & \multicolumn{4}{|c|}{ U16 } & \multicolumn{4}{|c|}{ U18 } \\
\hline & \multicolumn{2}{|c|}{ početnost' } & \multicolumn{2}{|c|}{ úspešnost' } & \multicolumn{2}{|c|}{ početnost' } & \multicolumn{2}{|c|}{ úspešnost' } \\
\hline & $6,25 \mathrm{~m}$ & $6,75 \mathrm{~m}$ & $6,25 \mathrm{~m}$ & $6,75 \mathrm{~m}$ & $6,25 \mathrm{~m}$ & $6,75 \mathrm{~m}$ & $6,25 \mathrm{~m}$ & $6,75 \mathrm{~m}$ \\
\hline $\mathbf{M}$ & 21,32 & 18,31 & 28,03 & 27,89 & 22,49 & 20,01 & 29,62 & 29,25 \\
\hline SD & 5,58 & 5,05 & 10,17 & 10,28 & 5,14 & 5,46 & 10,51 & 9,77 \\
\hline Me & 21 & 18 & 27,3 & 27,55 & 22 & 19,5 & 29,2 & 29,2 \\
\hline $\mathbf{x}_{\min }$ & 7 & 8 & 5,6 & 0 & 9 & 9 & 5,9 & 0 \\
\hline $\mathbf{x}_{\max }$ & 39 & 33 & 60 & 60 & 40 & 38 & 58,8 & 61,1 \\
\hline $\mathbf{R}$ & 32 & 25 & 54,4 & 60 & 31 & 29 & 52,9 & 61,1 \\
\hline
\end{tabular}

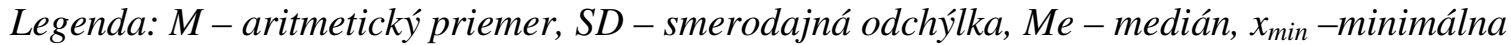
hodnota, $x_{\max }-$ maximálna hodnota, $R$ - variačné rozpätie

\section{ZÁVER}

Štúdia prezentuje rozdielnosti v početnosti a úspešnosti strel'by za 3 body, v kategóriách U16 a U18, ku ktorým došlo po zmene pravidiel o 3-bodovom území (posunutie horizontálnej vzdialenosti z 6,25 m na 6,75 m od koša) v roku 2010. Uplatnenie nového pravidla malo signifikantný vplyv na zníženie početnosti vystrelených 3-bodovýh pokusov v kategórií U16 na ME 2011, 2012 oproti ME 2009, 2010 (p < 0,01), ako aj v kategórií U18 na ME 2011, 2012 oproti ME 2009, 2010 (p < 0,01). Dôvodom zníženia početnosti 3-bodovej strel'by bola pravdepodobne zmena vo zvolených modeloch hry sledovaných družstiev a preferencia strel'by za 2 body. Pri porovnaní percentuálnej úspešnosti strel'by za 3 body neboli zistené štatistické významné rozdiely v kategórií U16 (p > 0,05), ani U18 (p > 0,05) medzi sledovanými ME 2009, 2010 a ME 2011, 2012. Ekvivalentnost' $v$ úspešnosti 3-bodovej strel'by bola pravdepodobne spôsobená vyššou fluktuáciou hráčskeho kádra v pozorovaných družstvách oboch kategórií.

Uvedené výsledky poukazujú na fakt, že posunutie horizontálnej vzdialenosti pre 3-bodovú strel'bu z 6,25 m na 6,75 nemalo štatisticky významný vplyv na úspešnost' strel'by za 3 body v U16, ani v U18. Na základe týchto zistení predpokladáme, že na budúcich vrcholových podujatiach, v kategóriách U16 a U18, dôjde k opätovnému zvýšeniu početnosti strel'by za 3 body. Na formuláciu všeobecnejšie platných záverov odporúčame zistené výsledky overit' d’alšími výskumnými šetreniami aj na iných vekových a výkonnostných kategóriách oboch pohlaví. Súhlasíme s názorom Tománka \& Kucsu (2012), že analýza početnosti a úspešnosti 
3-bodovej strel'by by mala byt' v čo najširšom časovom horizonte, aby bolo možné zaznamenat' vývojový trend a nie len aktuálny stav pozorovaného javu, ako sa to čiastočne podarilo v tomto prípade.

\section{LITERATÚRA}

Argaj, G. (2009). Nové prístupy $k$ hodnoteniu hráčskeho výkonu vo vrcholovom basketbale. Bratislava, Slovenská republika: Fakulta telesnej výchovy a športu Univerzity Komenského v Bratislave.

Argaj, G. (2011). Porovnanie plus/mínus bodov a hernej efektivity pri hodnotení individuálneho herného výkonu v basketbale. In Studia sportiva, 5 (1), 85-93.

Brodzinski, B. (2007). Shooting the Right Way. In FIBA Assist Magazine, 25, 4-11.

Erčulj, F. \& Supej, M. (2009). Impact of Fatigue on the Position of the Release Arm and Shoulder Girdle over a Longer Shooing Distance for an Elite Basketball Player. In Journal of Strength and Conditioning Research, 23 (3), 1029-1036.

FIBA. (2012). Official Basketball Rules 2012. Rio de Janeiro, Brazil: FIBA Central Board. Dostupné z: http://www.fiba.com/downloads/Rules/2012/OfficialBasketballRules2012.pdf

Goméz, M.A., Lorenzo, A., Sampaio, J., Ibáñez, S.J. \& Ortega, E. (2008). Game-Related Statistics that Discriminated Winning and Losing Teams from the Spanish Men's Professional Basketball Teams. In Collegium Antropologicum, 32 (2), 451-456.

Hendl, J. (2004). Přehled statistických metod zpracování dat: analýza a metaanalýza dat. Praha, Česká republika: Portál.

Chráska, M. (2007). Metody pedagogického výzkumu: základy kvantitativního výzkumu. Praha, Česká republika: Grada Publishing.

Ibáñez, S.J., García, J., Feu, S., Lorenzo, A. \& Sampaio, J. (2009). Effects of consecutive basketball games on the game-related statistics that discriminate winner and loosing teams. In Journal of Sports Science and Medicine, $8(3), 458-462$.

Krause, J., Meyer, D. \& Meyer, J. (2008) Basketball Skills and Drills (3 ${ }^{\text {rd }}$ ed). Champaign, IL, USA: Human Kinetics.

Lorenzo, A., Gómez, M.A., Ortega, E., Ibáñez, S.J. \& Sampaio, J. (2010). Game related statistics which discriminate between winning and losing under-16 male basketball games. In Journal of Sports Science and Medicine, 9 (4), 664-668.

Mačura, P. (2010). Biomechanika basketbalovej strel'by (2 ${ }^{\text {nd }}$ ed.). Olomouc, Česká republika: Univerzita Palackého v Olomouci.

McGee, K. \& ASEP. (2007). Coaching basketball: Technical and tactical skills. Champaign, IL, USA: Human Kinetics.

Miller, S. \& Bartlett, R. (1996). The relationship between basketball shooting kinematics, distance and playing position. In Journal of Sports Sciences, 14, 243-253.

Neto, J.M.M.D. (2007). The stats value for winning in the world basketball championship for men 2006. In Fitness Performance Journal, 6 (1), 57-61.

Oudejans, R.R.D. (2012). Effects of Visual Control Training on the Shooting Performance of Elite Female Basketball Players. In International Journal of Sports Science \& Coaching, 7 (3), 469-480.

Pates, J., Cummings, A. \& Maynard, I. (2002). The effects of hypnosis on flow states and three-point shooting performance in basketball players. In The Sport Psychologist, 16, 34-47.

Pojskić, H., Šeparović, V. \& Užičanin, E. (2009). Differences between successful and unsuccessful basketball teams on the final Olympic tournament. In Acta Kinesiologica, 3 (2), 110-114.

Tang, W.-T. \& Shung, H.-M. (2005). Relationship between isokinetic strength and shooting accuracy at different shooting ranges in Taiwanese elite high school basketball players. In Isokinetics and Exercise Science, 13, 169-174.

Tománek, L'. (2010). Teória a didaktika basketbalu. Bratislava, Slovenská republika: ICM Agency.

Tománek, L. \& Kucsa, R. (2012). Vplyv zmeny pravidla trojbodového územia na úspešnost' trojbodovej strel'by v basketbale. In M. Merica (Ed.), Vedecké práce 2012. (pp. 255-261). Bratislava, Slovenská republika: STU Bratislava.

Wissel, H. (2012). Basketball: Steps to Success ( $3^{\text {rd }}$ ed.). Champaign, IL, USA: Human Kinetics. 
History. U16 European Championship Men. FIBA Europe [online]. Munich, Germany: (C) 2013 FIBA Europe [cit. 2012-12-18] Dostupné z: http:/www.fibaeurope.com/cid_KNce8jInH7Qj1EsyH5rjn2.pageID_ic, OHMZFGR-1sU9wr1wFG2.compID_YUjW-7-FJ,kK9s431Lyr41.html

History. U18 European Championship Men. FIBA Europe [online]. Munich, Germany: (C) 2013 FIBA Europe [cit. 2012-12-19] Dostupné z: http:/www.fibaeurope.com/cid_KNce8jInH7Qj1EsyH5rjn2.pageID_ic, OHMZFGR-lsU9wr1wFG2.compID_8aYeHlfuGF-mF5IqO8aFH1.html 